\title{
Non-contact specular microscopy in aphakic and pseudophakic dogs
}

\author{
Microscopia especular de não contato em cães afácicos e em pseudofácicos
}

\author{
Claudia Emi Nagatsuyu ${ }^{\mathrm{I}}$ Priscila Barreto de Abreu ${ }^{\mathrm{I}}$ Karina Kamachi Kobashigawa ${ }^{\mathrm{I}}$ \\ Luciano Fernandes da Conceição ${ }^{I}$ Adriana Morales ${ }^{I}$ Alexandre Lima de Andrade ${ }^{I I}$ \\ Ivan Ricardo Martinez Padua ${ }^{\mathrm{I}}$ Bianca da Costa Martins ${ }^{\mathrm{III}}$ José Luiz Laus $^{\mathrm{I}}$
}

\section{ABSTRACT}

Cataract is one of the most common ocular diseases in dogs, and phacoemulsification is considered its treatment of choice. Posterior capsular opacity (PCO) is a frequent complication and may occur weeks or months after the surgery. It is known that intraocular lenses (IOL) used for the correction of post-operative hypermetropia are an adjunctive aid in the prevention of PCOs, mainly the foldable acrylics designs with square and truncated edges. However, IOL placement may result in endothelial cell loss. This study evaluated the morphology and cellularity of the endothelium by non-contact specular microscopy in aphakic and pseudophakic dogs. Endothelial cell density, endothelial cell area, coefficient of variation and hexagonal cells percent were analyzed for each group and between groups. During all evaluation periods, endothelial cell density did not alter in any group. From days 7 to 30, endothelial cell density was higher in pseudophakic dogs. However, values returned to normal and, by the end of the study, no significant difference was observed. Cell area and variation coefficient did not differ in each group or between groups. Hexagonal cells percent significantly reduced after phacoemulsification in both groups. With time, this condition returned to initial values. When both groups were compared, hexagonal cells percent were decreased in the pseudophakic group, immediately after the surgeries.

Key words: dog, intraocular lens, corneal endothelium, specular microscopy.

RESUMO

A catarata está entre as afecções oculares mais frequentes em cães, sendo a facoemulsificação o método que melhor se adequa à sua terapia. A opacidade de cápsula posterior (OCP) encontra-se entre as complicações mais comuns e se manifesta em semanas ou meses após a facectomia. Lentes intraoculares, empregadas na correção da hipermetropia póscirúrgica, contribuem para a prevenção das OCPs, especialmente as acrílicas dobráveis, com bordas truncadas ou quadradas. Entretanto, a sua implantação pode resultar na perda de células endoteliais. Com a pesquisa, propuseram-se avaliar a morfologia e a celularidade endoteliais, a microscopia especular de não contato, em pacientes afácicos e em pseudofácicos. Foram analisados a densidade celular, a área celular, o coeficiente de variação e o percentual de células hexagonais inter e entre os grupos. Ao longo dos momentos da avaliação, a densidade das células endoteliais não se alterou significativamente dentro dos grupos. Na comparação entre os grupos, ela foi maior nos pseudofácicos, em períodos que variaram de 7 a 30 dias, entretanto retornaram a valores próximos aos iniciais, tornando a diferença entre os dois grupos não significativa ao final da avaliação. Relativamente à área celular e ao coeficiente de variação, não houve diferença significativa, inter e entre os grupos. Houve diferença dentro dos grupos relativamente à hexagonalidade, com diminuição percentual após a facoemulsificação. As condições retornaram ao basal. Na comparação entre pacientes pseudofácicos e afácicos, houve diminuição nos pseudofácicos imediatamente à cirurgia.

Palavras chave: cão, lente intraocular, endotélio corneal, microscopia especular.

\section{INTRODUCTION}

Cataract is one of the most commonly observed ocular diseases in dogs and one of the mainly causes of vision loss in this species (BARNETT, 1985; GLOVER \& CONSTANTINESCU, 1997; CROIX, 2008). The disease is manifested when disarrange of the lenticular fibers occurs (MUNGER, 2009).

IDepartamento de Clínica e Cirurgia Veterinária, Faculdade de Ciências Agrárias e Veterinárias (FCAV), Universidade Estadual Paulista (UNESP), 14884-900, Jaboticabal, SP, Brasil. Email: jllaus@fcav.unesp.br. *Autor para correspondência

"Departamento de Clínica, Cirurgia e Reprodução Animal, Faculdade de Medicina Veterinária de Araçatuba (FMVA), UNESP, Araçatuba, SP, Brasil.

IIIDepartments of Small and Large Animal Clinical Sciences, University of Florida (UFL), Gainesville, FL, USA. 
Classifications modalities has been attributed to cataracts. Regarding the patient age, cataracts may be classified as congenital, neonatal, juvenile or senile (MUNGER, 2009). Regarding their development stage, they may be classified as incipient, immature, mature or hypermature (DAVIDSON \& NELMS, 2007).

Surgical approach is considered the best treatment choice (PIGATTO et al., 2007), since no topical, systemic or intraocular therapy is able to furnish reproducible satisfactory results that impairs cataract progression or results on the absorption of the cataractous lens (CROIX, 2008). Phacoemulsification is the most commonly accepted method for the removal of lens in animals (MUNGER, 2009) and hypermetropia correction with intraocular lenses (IOLs) is routinely performed. Harold Ridley was the pioneer in the procedure in humans, in 1949. The use of polymethyl metacrylate (PMMA) lenses requires a cornea incision of at least $8 \mathrm{~mm}$ for its placement. Lately foldable IOLs became available, which permitted their placement though smaller corneal incisions (KECOVÁ \& NECAS, 2004). In dogs, IOLs of 41.5 dioptries (D) are used, while 53D IOLs are the standard for cats (GILGER, 2007).

Posterior capsular opacity (PCO) is one of the most common complications after lens removal and may be observed in up to $100 \%$ of the cases (SIGLE $\&$ NASSISSE, 2006). The use of IOLs, mainly those acrylic designs with square and truncated edges, may prevent PCO occurrence (DAVIDSON \& NELMS, 2007; KUGELBERG et al., 2008; LI et al., 2008).

Despitetheremarkablephacoemulsification advantages compared to other surgical techniques, the endothelial damage resulted from the method is a complication that needs to be addressed. The presence of IOLs may also induce endothelial cell loss (GWIN et al., 1983), however its occurrence has been gradually reduced with the use of improved viscoelastic agents (GILGER, 2007).

The dog's cornea is composed of preocular tear film, corneal epithelium, stroma, Descemet's membrane and endothelium (SAMUELSON, 2007). The endothelium is a single layer of juxtaposed cuboidal cells with pale and granular cytoplasm, which act in the transport of fluids and maintenance of corneal transparency (SAMUELSON, 2007; RODRIGUES, 1999; GALERA et al., 2009). Most of the endothelial cells exhibit hexagonal shape and, in dogs, their average density is 2500 cells. $\mathrm{mm}^{-2}$. With age, endothelial cells increase in size while decreases in number, and senile dogs frequently have an average density of up to 2100 cells.mm ${ }^{-2}$ (SAMUELSON, 2007; RODRIGUES, 1999).
Specular microscopy is a non-invasive technique of easy execution. Its principle is based on the reflection of a light source inciding over the corneal endothelium surface, in which part is specular reflected and captured. A pool of electronic devices magnifies the endothelial image. Two types of specular microscope are available: contact and noncontact. Both devices may be used for the evaluation of endothelial cells morphology and density (KÄLLBERG, 2007). The captured image is directed to software and qualitatively and quantitatively analyzed. The quantitative analysis is the estimation of endothelial cells density. The qualitative evaluation takes in consideration the average size and shape of the cells (ABIB, 2000; PHILIPS et al., 2005).

Due to the increasing number of dogs receiving intraocular lenses and considering the pros and cons of the procedure, especially those regarding endothelial cells damage, this study evaluated the endothelial conditions of aphakic and pseudophakic dogs by non-contact specular microscopy.

\section{MATERIAL AND METHODS}

Dogs of different breeds, males and females, presented at the Ophthalmology Unit of the Sao Paulo State University Veterinary Hospital - "Governador Laudo Natel" - Jaboticabal/SP - Brazil, were used. Patients were submitted to routine ophthalmic examination based on menace and dazzle reflexes, Schirmer's tear test (Teste de Schirmer ${ }^{\circledR}$, Ophthalmos, Brazil), slit lamp biomicroscopy (SL-14 - Portable Slit Lamp $^{\circledR}$, Kowa, Japan), gonioscopy (Koeppe Medium Diagnostic Lens ${ }^{\circledR} 18 \mathrm{~mm}$, Ocular Instruments Inc., USA), indirect (FCV 2000 ${ }^{\circledR}$, Eyetech, USA) and direct ophthalmoscopy $\left(7100^{\circledR}-\mathrm{C}\right.$, Welch Allyn, USA), applanation tonometry (Tono-Pen Vet ${ }^{\circledR}$, Reichert) and fluorescein staining (Fluoresceina strips ${ }^{\circledR}$, Ophthalmos, Brazil). Also, animals were submitted to ocular ultrasonography (UltraScan Imaging System ${ }^{\circledR}$ - Alcon do Brasil AS, Brazil) and electroretinography (Handheld Multi-species ERG $^{\circledR}$ - RetVetCorp, Colombia). All assessments were made by the same observer.

Dogs aging between 3 to 7 years old presenting with immature or mature bilateral cataract, free of systemic or other ocular diseases and without intraocular inflammation sequelae were selected. A complete physical examination, cell blood count, liver and renal evaluation and glycemic index were performed.

A total of 20 dogs were selected. Patients were randomly assigned (coin tossing) in two groups (G1 - pseudophakic; G2 - aphakic), composed of 10 dogs each. All patients were submitted to bilateral 
bimanual phacoemulsification (Facoemulsificador universal II ${ }^{\circledR}$, Alcon do Brasil AS, Brazil), performed by the same surgeon. As irrigation solution, balanced saline solution was used, added epinephrine (Epinefrina $^{\circledR}$, Cristália, Brazil) 1:1000 (1ml) and heparin sodium (Heparina sódica ${ }^{\circledR}$, Ariston Ltda, Brazil) (1ml). Nucleus fracture was performed by "divide and conquer" technique. Group 1 patients received foldable acrylic IOL (30-V 12,0/30-V $14,0^{\circledR}$, Acrivet, Germany) followed by intracameral administration of $0.01 \%$ carbacol chloride $\left(\mathrm{Ophtcol}^{\circledR}\right.$, Ophthalmos, Brazil) (0.5 ml) (STHR et al, 1998) in both eyes. Group 2 patients were kept aphakic.

Following surgery, patients received systemic prednisone (Meticorten ${ }^{\circledR}$, Schering Ploug, Brazil) (1 mg. $\left.\mathrm{kg}^{-1}\right)$ every 24 hours for 15 days, topical dexamethasone associated to tobramycin (Tobradex ${ }^{\circledR}$, Alcon Laboratórios do Brasil AS, Brazil) ( $q 4$ h) for at least 30 days, $1 \%$ brinzolamide $\left(\right.$ Azopt $^{\circledR}$, Alcon Laboratórios do Brasil AS, Brazil) (q12 h) and 1\% tropicamide $\left(\right.$ Mydriacyl ${ }^{\circledR}$, Alcon Laboratórios do Brasil AS, Brazil) (q8 h) for up to 7 days. Patients wore an elizabethan collar for at least 15 days.

Animals were evaluated immediately following surgeries and at days 7, 14, 21, 30, 45 and 60. Post-operative examinations were performed as previously reported for patient selection. Endothelial conditions were studied by non-contact specular microscopy (SP-3000P ${ }^{\circledR}$, Topcon, Japan) (Figure 1) after intravenous anesthesia with propofol (Propovan ${ }^{\circledR}$, Cristália, Brazil) $\left(5 \mathrm{mg} \cdot \mathrm{kg}^{-1}\right)$. In order to not cause variations on the results, all the animals were positioned by the same person.

During a previous pilot study, it was revealed to be difficult to obtain satisfactory images of the corneal endothelium, since the beam of light reflected both in the opaque lens and corneal endothelium. In order to overcome this obstacle, topical latanoprost $\left(\right.$ Xalacom ${ }^{\circledR}$, Pfizer, Brazil) was administered. The resulted miosis impaired the reflection of the light over the lens. The drug was instilled 30 minutes before the examination.

Specular images were obtained from central corneal area (Figure 2). Parameters evaluated included endothelial cell density (cells. $\left.\mathrm{mm}^{-2}\right)$, hexagonality $(\%)$ and area $\left(\mu \mathrm{m}^{2}\right)$, as well as coefficient of variation $(\mathrm{CV})$. The values obtained were transferred to "software Cell Count".

Repeated test analysis of variance (ANOVA) was used to evaluate the effect of treatment (IOL implantation or not) by time. Data was also analyzed by Tukey's test. For all analysis, a value of $\mathrm{P}<0.05$ was considered to be statistically significant.

\section{RESULTS AND DISCUSSION}

Ultrasonographic examinations permitted the evaluation of vitreal aspect, the measurement of natural lenses and the establishment artificial IOL size to be used in each case (12 $\mathrm{mm}$ or $14 \mathrm{~mm}$ ). Electroretinography assured the normal function of retinal cones and rods. Clinical parameters observed on ocular examination did not differ between groups and were the expected for a routine post-operative phacoemulsification period. Endothelial cells density did not differ in pseudophakic dogs $(\mathrm{P}=0.3883)$ or in aphakic dogs $(\mathrm{P}=0.0757)$ throughout the study period. When both groups were compared, a significant difference on average cell density was observed on day $7(\mathrm{G} 1=2805.65 \pm 627.06 ; \mathrm{G} 2=1694.47 \pm 80.32)$, day $14(\mathrm{G} 1=2311.5 \pm 242.55 ; \mathrm{G} 2=1302.91 \pm 81.9)$, day 21

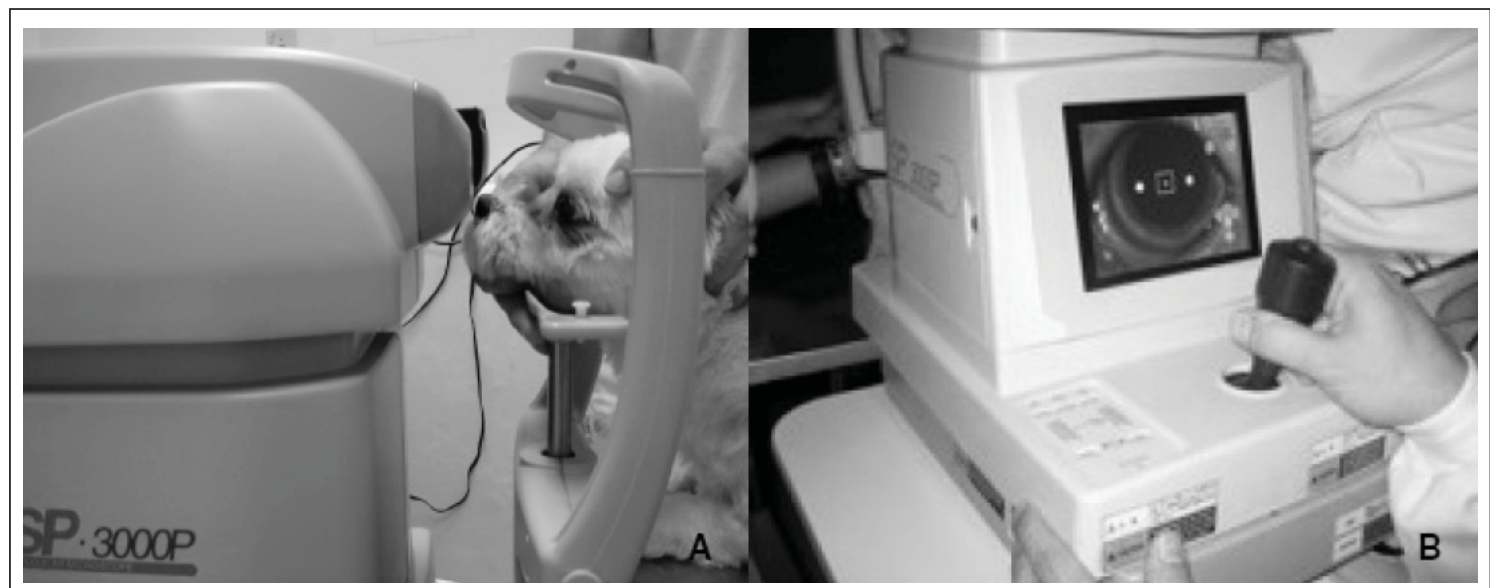

Figure 1 - Photographic images of non-contact specular microscopy (SP-3000 $\mathrm{P}^{\circledR}$ specular microscope - Topcon, Japan). (A) Canine patient positioned for image capture. (B) Equipment screen showing the frontal image of patient's eye immediately before image capture. Ophthalmology Unit, FCAV/UNESP, Jaboticabal, SP, Brazil, 2012. 


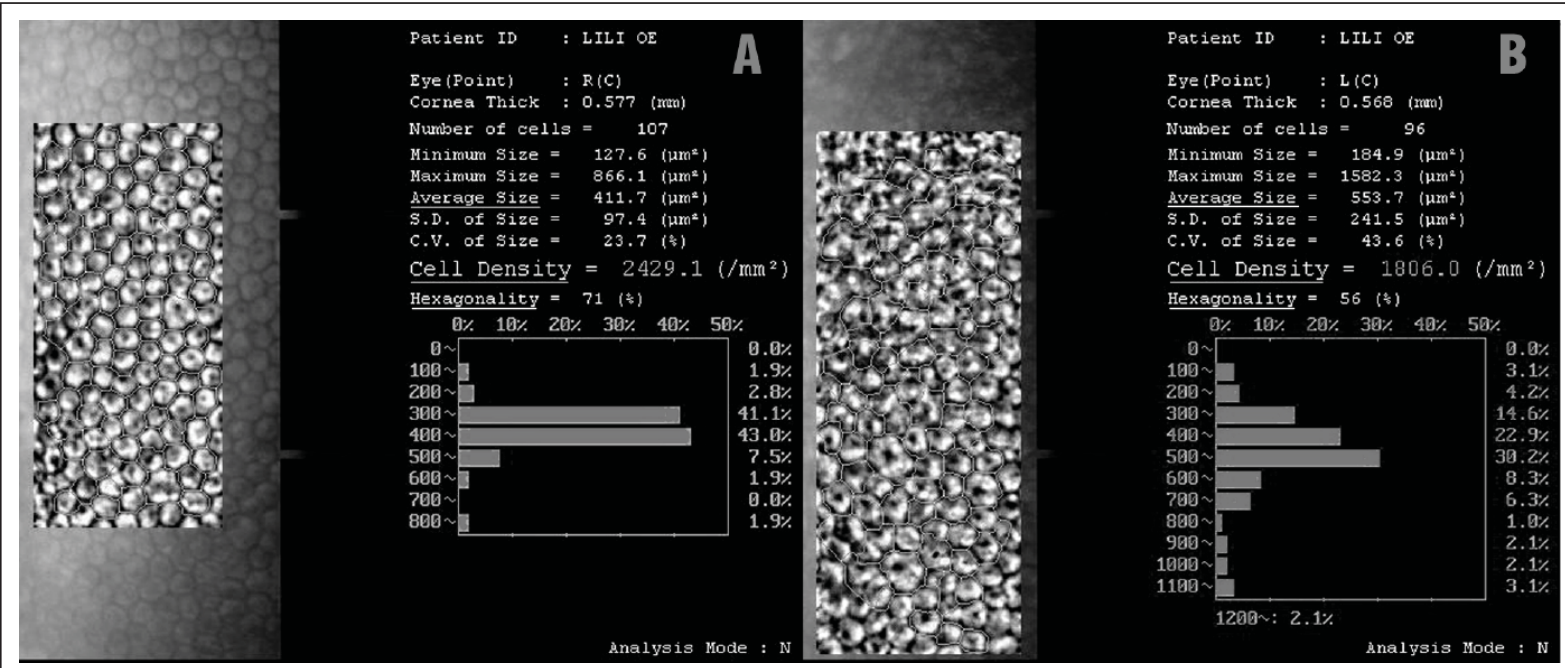

Figure 2 - Photographic images of non-contact specular microscopy (SP-3000P ${ }^{\circledR}$ specular microscope - Topcon, Japan). (A) Image of normal corneal endothelium before phacoemulsification. (B) Image of corneal endothelium of the same patient 7 days after phacoemulsification and implant of intraocular lens. Note modified morphology of the cells, average size, cell density and hexagonality. Ophthalmology Unit, FCAV/UNESP, Jaboticabal, SP, Brazil, 2012.

$(\mathrm{G} 1=2375.61 \pm 424.65 ; \mathrm{G} 2=1406.16 \pm 58.03)$ and day 30 (G1=2968.65 $\pm 560.23 ; \mathrm{G} 2=1932.61 \pm 28.55)$ following surgery, however on days $45(\mathrm{G} 1=2302.01 \pm 250.09$; $\mathrm{G} 2=2109.18 \pm 46.81)$ and $60(\mathrm{G} 1=2258.05 \pm 263.35$; $\mathrm{G} 2=2158.36 \pm 75.7)$ it was not observed.

Average cell area did not differ in pseudophakic dogs $(\mathrm{P}=0.6012)$ or in aphakic dogs $(\mathrm{P}=0.5701)$ throughout the study period. Similarly, the coefficient of variation did not differ in pseudophakic $(\mathrm{P}=0.2168)$ and aphakic dogs $(\mathrm{P}=0.437)$. When both groups were compared, no significant difference on average cell area and coefficient of variation were observed at any moment of evaluation.

Endothelial cells hexagonality decreased immediately after surgery in pseudophakic dogs (18.9 \pm 7.72$)$ and returned to baseline values at day 14 (33.2 \pm 10.45$)$. In aphakic patients, values returned to baseline at day 30 (61.1 \pm 3.69$)$. A significant difference was observed between groups immediately after surgery $(\mathrm{G} 1=23.4 \pm 9.74 ; \mathrm{G} 2=46.0 \pm 9.04)$, day $7(\mathrm{G} 1=18.9 \pm 7.72$; $\mathrm{G} 2=45.6 \pm 5.19), \quad$ day $\quad 30 \quad(\mathrm{G} 1=15.5 \pm 9.01$; $\mathrm{G} 2=61.1 \pm 3.69)$, day $45(\mathrm{G} 1=14.5 \pm 7.98 ; \mathrm{G} 2=62.4 \pm 3.41)$ and day $60(\mathrm{G} 1=28.3 \pm 10.15 ; \mathrm{G} 2=70.8 \pm 4.06)$ after phacoemulsification.

RODRIGUES (1999) and ABIB \& BARRETOS (2001) showed that corneal cell density decreases with age. Besides aging influence, several factors, such as trauma and intraocular inflammation, may lead to endothelial loss (TUFT \& COSTER, 1990; PIGATTO et al., 2005).

Phacoemulsification, followed by IOL placement or not, may induce various complications resulting from direct trauma during the introduction of the phaco unit handpiece or other instruments, as well as intraoperative manipulation (TRONCA et al., 2005). Endothelial cell damage may be triggered since the initial corneal incision, and its risks increase during surgery. The most commonly implicated causes for endothelial cells loss are the irrigation solution volume, fluid turbulence and increased intraocular temperature. Direct trauma caused by surgical instruments, lenses fragment and IOL placement may also play a role on cellular damage (ANDRADE, 2011 - personal comunication). Endothelial alterations are important parameters to be considered when evaluating the safety of intraocular surgeries. A decrease on endothelial cells hexagonality has been reported following penetrating keratoplasty and cataracts removal (TUFT \& COSTER, 1990).

Refractive correction is not considered essential in dogs. However, it offers a significant improvement on visual acuity, mainly when near focus is necessary. A good prognosis for vision quality is reported in dogs following acrylic IOLs (KLEIN et al., 2011).

The development of phacoemulsification through minimal corneal incision associated to the use of foldable IOLs has decreased the PCO incidence (KUGELBERG et al., 2008). The "barrier effect" offered by IOLs with square and truncated edges significantly reduces PCO development (GIFT et al., 2009). Advanced viscoelastic agents and drugs are also beneficial and improve the surgical outcome (WILKIE \& COLITZ, 2007). 
The clinical evaluation data obtained in this study are similar to the findings of RODRIGUES et al. (2010) which reported the occurrence of uveitis following phacoemulsification in pseudophakic and aphakic patients. Moreover, the clinical signs were more severe during early post-operative period. RODRIGUES et al. (2010) reported that uveitis could be observed for longer periods in pseudophakic patients, compared to aphakic dogs. It is postulated that the increased surgical time and intraocular manipulation necessary for the IOL placement might contribute to this observation. In the present study, no difference on uveitis manifestation was observed when both groups were compared.

CHIURCIU et al. (2010) reported a significant decrease on endothelial cells density following phacoemulsification in dogs. The same was not observed in the present study. Our findings are in accordance to reports by STUMPF \& NOSÉ (2006), whom did not find significant differences on endothelial cells density before and after phacoemulsification.

In the present study, a significant decrease of endothelial cells hexagonality was observed in both groups. This aspect returned to baseline values in the final periods of the research. PIGATTO et al. (2008) reported that the majority of the endothelial cells in dogs exhibit hexagonal shape (65-80\%).

Endothelial cells area and coefficient of variation were similar for both groups. CHIURCIU et al. (2010) reported an increase on endothelial cells area for up to 60 days following phacoemulsification.

\section{CONCLUSION}

Based on the results obtained with this study, it is possible to admit that IOL placement does not induce significant endothelial cell damage, when compared to aphakic patients.

\section{ACKNOWLEDGEMENT}

The authors acknowledge the financial support from São Paulo Research Foundation (FAPESP - process number 2009/51773-4 and 2010/18605-8) and Brazilian Federal Agency for Support and Evaluation of Graduate Education and National Counsel of Technological and Scientific Development (process $\mathrm{n}^{\circ}$ 300833/2010-5).

Personal comunication: ANDRADE, A.L., 2011, Department of Animal Clinics, Surgery and Reproduction, College of Veterinary Medicine, Sao Paulo State University, Araçatuba, SP, Brazil (landrade@fmva.unesp.br). European College of Veterinary Ophthalmologists Congress, May 2012, Poster presentation.

\section{COMMITTEE OF ETHICS AND ANIMAL WELFARE}

The study protocol was submitted to and approved by the Committee of Ethics and Animal Welfare of the College of Agricultural and Veterinarian Sciences - UNESP - Jaboticabal (Protocol 001686/11).

\section{REFERENCES}

ABIB, F.C. Microscopia Especular de Córnea. Rio de Janeiro: Revinter-RioMed, p. 19-24, 2000.

ABIB, F.C.; BARRETOS, J. Behavior of corneal endothelial density over a lifetime. Journal of Cataract \& Refractive Surgery, v.27, p.1574-1578, 2001. Available in: <http://europepmc.org/abstract/MED/11687354>. Acess in: 4 set. 2012. DOI: 10.1016/S0886-3350(01)00925-7

BARNETT, K.C. The diagnosis and differential diagnosis of cataract in the dog. Journal of Small Animal Practice, v.26, n.6, p.305-\&, 1985. Available in: <http://onlinelibrary.wiley.com/ doi/10.1111/j.1748-5827.1985.tb02204.x/abstract> Acess in: 20 fev. 2012. DOI: 10.1111/J.1748-5827.1985.TB02204.X

CHIURCIU, J.L.V.; BRANDÃO, C.V.S.; RODRIGUES, A.C.L. et al. Uso de viscoelásticos na facoemulsificação em cães portadores de catarata: efeitos sobre a pressão intraocular, a morfologia das células endoteliais e a espessura corneana. Arquivos Brasileiros de Medicina Veterinária e Zootecnia, v.62, n.35, p.70-577, 2010. Available in: <http://www.scielo.br/scielo.php?pid=S0102$09352010000300011 \&$ script $=$ sci arttext $>$. Acess in: 10 jun. 2012 DOI: $10.1590 / \mathrm{S} 0102-09352010000300011$

CROIX, N.L. Cataracts: When to refer. Topics in Companion Animal Medicine, v.23, n.1, p.46-50, 2008. Available in: <http:// pubget.com/paper/18544332/Cataracts_When_to_Refer $>$. Acess in: 18 jan. 2012. DOI: $10.1053 /$ j.ctsap. $\overline{2007.12 .006}$

DAVIDSON, M.G.; NELMS, S.R. Diseases of the lens and cataract formation. In: GELATT K.N. Veterinary Ophthalmology. Iowa: Blackwell Publishing, 2007. v.2, p.862-881.

GALERA, P.D.; LAUS, J.L.; ORIÁ, A.P. Afecções da túnica fibrosa. In: LAUS, J.L. Oftalmologia clínica e cirúrgica em cães e em gatos. São Paulo: Roca, 2009. p.69-71.

GIFT, B.W. et al. Comparison of capsular opacification and refractive status after placement of three differente intraocular lens implants following phacoemulsification and aspiration of cataracts in dogs. Veterinary Ophthalmology, v.12, p.13-21, 2009. Available in: <http://www.ncbi.nlm.nih.gov/pubmed/19152593>. Acess in: 4 set. 2012. DOI: 10.1111/j.1463-5224.2009.00667.x.

GILGER, B.C. Cristalino. In: SLATTER, D. Manual de cirurgia de pequenos animais. Barueri: Manole, 2007. v.2, p.1409-1417.

GLOVER, T.D.; CONSTANTINESCU, G.M. Surgery for cataract. Veterinary Clinics of North American: Small Animal Practice, v.27, n.5, p.1143-1173, 1997. Available in: <http://www.ncbi.nlm. nih.gov/pubmed/9326971>. Acess in: 30 jan. 2012.

GWIN, R.M et al. Effects of phacoemulsification and extracapsular lens removal on corneal thickness and endothelial cell density in the dog. Investigative ophthalmology \& Visual science, v.24, p.227-236, 1983. Available in: <http://www.ncbi.nlm.nih.gov/ pubmed/6826326>. Acess in: 20 aug. 2012.

KÄLLBERG, M.E. Ophthalmic Examination and Diagnostics-Part 2: Ocular Imaging. In: GELATT, K.N. Veterinary Ophthalmology, Iowa: Blackwell Publishing, 2007. v.1, p.496. 
KECOVÁ, H.; NECAS, A. Phacoemulsification and intraocular lens implantation: recent trends in cataract surgery. Acta Veterinaria Brno, v.73, p.85-92, 2004. Available in: <http:// actavet.vfu.cz/73/1/0085/>. Acess in: 4 jul. 2012. DOI: $10.2754 /$ avb200473010085

KLEIN, H.E et al. Postoperative complications and visual outcomes of phacoemulsification in 103 dogs. Veterinary Ophthalmology, v.14, n.2, p.114-120, 2011. Available in: <http:// www.ncbi.nlm.nih.gov/pubmed/21366827>. Acess in: 4 nov. 2012 DOI: $10.1111 /$ j.1463-5224.2010.00853.x.

KUGELBERG, M. et al. Two-year follow-up of posterior capsule opacification after implantation of a hydrophilic or hydrophobic acrylic intraocular lens. Acta Ophthalmologica, v.86, p.533536, 2008. Available in: <http://www.ncbi.nlm.nih.gov/ pubmed/18081899>. Acess in: 5 out. 2012.

LI, N. et al. Effect of Acrysof versus silicone or polymethyl methacrylate intraocular lens on posterior capsule opacification. Ophthalmology, v.115, n.5, p.830-838, 2008. Available in: <http:// www.ncbi.nlm.nih.gov/pubmed/17964657>. Acess in: 3 aug. 2012.

MUNGER, R.J. Catarata. In: LAUS, J.L. Oftalmologia clínica e cirúrgica em cães e em gatos, São Paulo: Roca, 2009. p.111-115.

PHILIPS, C.; LAING, R.; YEE, R. Specular Microscopy. In: KRACHMER, J.H.; MANNIS, M.J.; HOLLAND, E.J. Cornea, London: Elsevier Mosby, 2005. p.261- 281.

PIGATTO, J.A.T. et al. Análise morfométrica do endotélio corneano de coelhos à microscopia eletrônica de varredura. Acta Scientiae Veterinariae, v.33, p.41-45, 2005. Available in: <http://www. redalyc.org/articulo.oa?id=289021867004>. Acess in: 3 jan. 2012.

PIGATTO, J.A.T. et al. Advantages and benefits of the phacoemulsification. Acta Scientiae Veterinariae, v.35, p.248249, 2007. Available in: <http://www.ufrgs.br/actavet/35-suple2/035-s2.htm>. Acess in: 3 mar. 2012.

PIGATTO, J.A.T.; CERVA, C.; FREIRE, C.D. et al. Morphological analysis of the corneal endothelium in eyes of dogs using specular microscopy. PesquisaVeterinária Brasileira, v.28, n.9, p.427-430, 2008. Available in: <http://www.scielo.br/scielo.php?pid $=\mathrm{S} 0100-$ 736X2008000900006\&script=sci_arttext $>$. Acess in: 7 jul. 2012. DOI: $10.1590 / \mathrm{S} 0100-736 \mathrm{X} 2008000900006$

RODRIGUES, G.N.; LAUS, J.L.; SANTOS, J.M.; RIGUEIRO, M.P.; SMITH, R.L. Corneal endothelial cell morphology of normal dogs in different ages. Veterinary Ophthalmology, v.9, n.2, p.101-107, 2006. Available in: <http://onlinelibrary.wiley.com/ doi/10.1111/j.1463-5224.2006.00427.x/pdf $>$.

RODRIGUES, G.N. et al. Facoemulsificação em cães, com e sem implante de lente intraocular em piggyback: estudo clínico da inflamação pós-operatória. Pesquisa Veterinária Brasileira, n.30, n.2, p.103-107, 2010. Available in: < http://www.scielo.br/ scielo.php?script $=$ sci arttext\&pid $=$ S0100-736X2010000200001\& lng=en\&nrm=iso $>$. Acess in 12 set. 2011. DOI: 10.1590/S0100736X2010000200001

SAMUELSON, A.D. Physiology of the eye. In: GELATT, K.N. Veterinary Ophthalmology, 2007. Iowa: Blackwell Publishing. v.1, p.98-109.

SIGLE, K.J.; NASISSE, M.P. Long-term complications after phacemulsification for cataract removal in dogs: 172 cases (19952002). Journal American Veterinary Medical Association, v.228, n.1, p.74-79, 2006. Available in: <http://www.ncbi.nlm.nih. gov/pubmed/16426170>. Acess in: 1 feb. 2012

STHR, C.M. et al. Effects of intracameral administration of carbachol on postoperactive increase in intraocular pressure in dogs undergoing cataract extraction. Journal American Veterinary Medical Association, v.212, p.1885-1888, 1998. Available in: <http://www. ncbi.nlm.nih.gov/pubmed/9638186>. Acess in: 4 apr. 2012.

STUMPF S., NOSÉ W. Estudo do endotélio corneano em cirurgias de cataratas duras: extração extracapsular planejada da catarata e facoemulsificação. Arquivos Brasileiros de Oftalmologia, v. 69, n.4, p.491-496, 2006. Available in: <http://www.scielo.br/scielo. php? script $=$ sci arttext\&pid $=$ S0004-27492006000400007\&lng $=$ en\&nrm=iso $>$. Acess in: 23 aug. 2011. DOI: 10.1590/S000427492006000400007

TRONCA, G.A. et al. Prognóstico visual na cirurgia de facoemulsificação da catarata com implante de lente intraocular. Arquivos catarinenses de medicina, v.34, n.2, p.39-48, 2005. Available in: <http://www.acm.org.br/revista/pdf/artigos/283. pdf $>$. Acess in: 12 mar. 2013.

TUFT, S.J.; COSTER, D.J. The corneal endothelium. Eye, v.4, p.389-424, 1990. Available in: < http://www.ncbi.nlm.nih.gov/ pubmed/2209904>. Acess in: 28 jan. 2012.

WILKIE, D.A.; COLITZ, C.M.H. Surgery of the canine lens. In: GELATT, K.N. Veterinary Ophthalmology, 2007. Iowa: Blackwell Publishing. v.2, p.905. 